\title{
'Saint-Pierre' Strawberry
}

\author{
Shahrokh Khanizadeh ${ }^{1}$, Johanne Cousineau, Martine Deschênes, \\ Audrey Levasseur, and Odile Carisse
}

Agriculture and Agri-Food Canada,Horticultural Research and Development Centre, 430 Gouin Boulevard, St-Jean-sur-Richelieu, QC, Canada, J3B $3 E 6$

\section{Jennifer DeEIl}

Ontario Ministry of Agriculture, and Food, 4890 Victoria Avenue N, Box 8000, Vineland Station, ON, Canada, LOR 2EO

\section{Louis Gauthier}

Les Fraises de l' ille d'Orléans Inc., St-Laurent, Île d'Orléans, QC, Canada, G0A $3 Z 0$

\section{J. Alan Sullivan}

University of Guelph, Department of Plant Agriculture, Edmund C. Bovey Building, Guelph, ON, Canada, N1G 2W1

Additional index words. Fragaria $\times$ ananassa, fruit breeding, storage, shelf life, red stele

'Saint-Pierre' is a new June bearing strawberry cultivar (Fragaria $\times$ ananassa Duch.) bred for Eastern Central Canada and climates similar to Quebec conditions. 'Saint-Pierre' was released because of its very large, firm light red colored fruit (Fig. 1) that last several days after maturing (Khanizadeh, 1994). The fruit do not darken during storage and have a similar level of antioxidants (Gallic Acid, Protocatecuic A., Catechin, P-hydroxybenzoic A., Epicatechin, and Ellagic Acid) as other cultivars with good shelf life (Hébert et al., 2002). 'Saint-Pierre' is useful for growers who need to store fruit for several days before marketing.

This new cultivar was named for SaintPierre village located in Ile d'Orléans, Quebec. The area is well known for its production of horticultural crops, including strawberries. 'Saint-Pierre' was first licensed to Les Fraises de l'Ile d'Orléans, located in Saint-Pierre.

\section{Origin}

'Saint-Pierre', tested as SJ89264-6, is a progeny resulting from a cross between 'Chandler' and 'Jewel' made in 1989 by S. Khanizadeh (Fig. 2). 'Saint-Pierre' has been tested at the Agriculture and Agri-Food Canada substation in L'Acadie, Quebec since 1990, and at the Macdonald Campus of McGill Univ. in Ste-Anne-de-Bellevue during 199294. It was also evaluated from 1996-98 in controlled semi-commercial sites by our private partners Lareault, Les Fraises de l'Ile d'Orléans, Réseau d'Essais de Petits FruitsCPVQ (Quebec Regional small fruit trials, Conseil des productions végétales du Québec) in Quebec and also in Europe by Meiosis

Received for publication 16 July 2001. Accepted for publication 24 Dec. 2001. Agriculture and AgriFood Canada, St-Jean-sur-Richelieu, Contribution No. 335/2002.10.01R.

${ }^{1}$ To whom reprint requests should be addressed. E-mail address:khanizadehs@em.agr.ca
(Bradbourne House, Stable Block, East Malling, Kent, Me196DZ, U.K.) and Haberli AG nursery.

\section{Description and performance}

Plants of 'Saint-Pierre' are vigorous, have an upright growing habit, and produce $2-5$ inflorescences per crown. They can tolerate winter temperatures below $-30{ }^{\circ} \mathrm{C}$ (with $10 \mathrm{~cm}$ straw mulch cover). Petioles are 10-15 $\mathrm{cm}$ long with three large, light green, slightly cupped, shiny, and obtuse leaflets, each with 24-30 serrations. The terminal leaflets have a 1 length : 1 width ratio and the flowers are perfect.

'Saint-Pierre' produces attractive and very large, light red, shiny fruit (Tables 1 and 2). The fruit color tends to be yellowish red when the plants are grown in light soils. The fruit shape is globose to conic. The flesh is orangered throughout and firm to very firm. Fresh fruit store well for up to $5 \mathrm{~d}$ at room temperature. European annual cultivar testing in Belgium reported similar observations on fruit color, shelf life, and firmness (Meiosis Annual Report, Kent, U.K.).

'Saint-Pierre' produced significantly lower yields than 'Kent' and 'Chambly' but was similar to the other cultivars tested. 'SaintPierre' is a late cultivar. The fruit started ripening 1-2 d before 'Bounty' at our substation in L'Acadie and the production peak was reached faster than that of 'Bounty' (Table 1).

Some symptoms of powdery mildew were noted on 'Saint-Pierre' plants especially during prolonged high humidity. However, plants appeared less susceptible to mildew than 'Bounty' and 'Kent'. 'SaintPierre' plants were as susceptible as

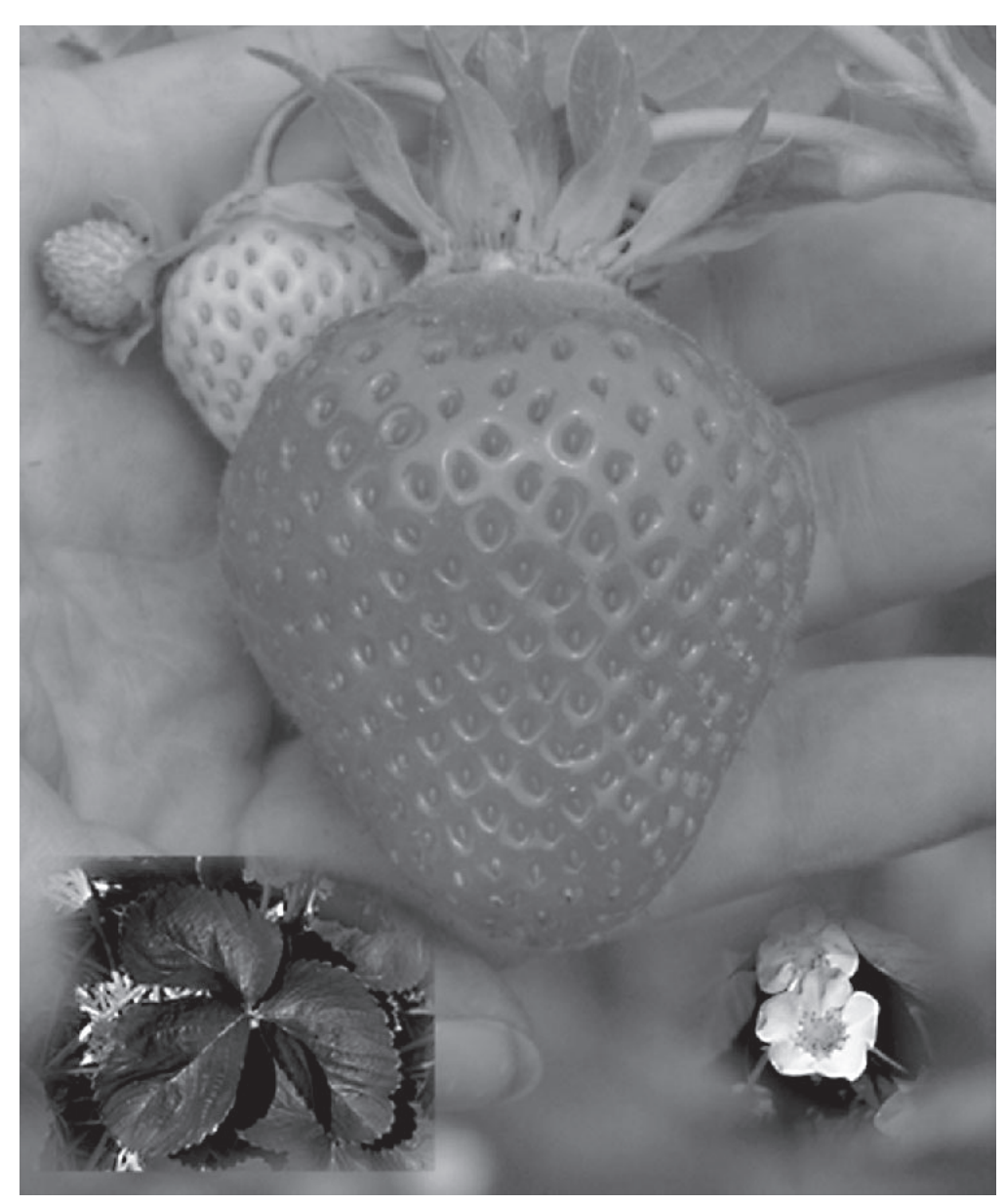

Fig. 1. Fruit, leaf, and flower of 'Saint-Pierre' strawberry. 
Table 1. Yield distribution ( $\mathrm{g} \cdot \mathrm{m}^{-1}$ of row), total yield, fruit weight, ripening season, index of crop concentration, and earliness of 'Saint-Pierre' and comparison cultivars at the L'Acadie site.

\begin{tabular}{|c|c|c|c|c|c|c|c|c|c|c|c|c|}
\hline \multirow[b]{2}{*}{ Cultivar } & \multicolumn{7}{|c|}{ Harvest $^{\mathrm{z}}$} & \multirow[b]{2}{*}{$\begin{array}{l}\text { Total yield } \\
\left(\mathrm{g} \cdot \mathrm{m}^{-1}\right)^{\mathrm{y}}\end{array}$} & \multirow[b]{2}{*}{$\begin{array}{l}\text { Wt/fruit } \\
(\mathrm{g})^{\mathrm{y}}\end{array}$} & \multirow[b]{2}{*}{$\begin{array}{l}\text { Ripening } \\
\text { season }^{\mathrm{x}}\end{array}$} & \multirow[b]{2}{*}{$\begin{array}{l}\text { Index of crop } \\
\text { concn }^{w}\end{array}$} & \multirow[b]{2}{*}{$\begin{array}{c}\text { Index of } \\
\text { earliness }^{\mathrm{w}}\end{array}$} \\
\hline & $\begin{array}{c}1 \\
(1)\end{array}$ & $\begin{array}{c}2 \\
(6)\end{array}$ & $\begin{array}{l}3 \\
(9)\end{array}$ & $\begin{array}{c}4 \\
(13)\end{array}$ & $\begin{array}{c}5 \\
(16)\end{array}$ & $\begin{array}{c}6 \\
(22)\end{array}$ & $\begin{array}{c}7 \\
(28)\end{array}$ & & & & & \\
\hline Kent & 817 & 885 & 885 & 769 & 510 & 526 & 307 & 3901 & 9.6 & $\mathrm{M}$ & 0.6 & 2.5 \\
\hline Chambly & 1182 & 931 & 972 & 650 & 524 & 313 & --- & 3987 & 9.4 & EM & 1.2 & 2.9 \\
\hline Bounty & 60 & 323 & 26 & 974 & 973 & 944 & 636 & 3266 & 9.7 & $\mathrm{~L}$ & 1.0 & 1.6 \\
\hline Honeoye & 1389 & 687 & 593 & 435 & 591 & 312 & 444 & 3340 & 8.0 & EM & 1.1 & 3.0 \\
\hline Saint-Pierre & 86 & 194 & 1087 & 1587 & 588 & 468 & --- & 3450 & 14.1 & $\mathrm{~L}$ & 1.9 & 1.6 \\
\hline $\mathrm{LSD}_{0.05}$ & & & & & & & & 421 & 1.5 & & 0.6 & 1.1 \\
\hline
\end{tabular}

${ }^{2}$ Average of the number of times fruit were harvested during the season; the number in brackets is the average cumulative day after the first harvest from second year plantings in 1995-98.

${ }^{y}$ Averaged over 4 years from second year plantings (1995-98), minimum of four replications per year, data taken from a 1-m long representative portion of a $2-\mathrm{m}$ matted row $($ width $=50 \mathrm{~cm}$ ).

${ }^{\times} \mathrm{L}=$ late, $\mathrm{LM}=$ late-midseason, $\mathrm{M}=$ midseason, $\mathrm{EM}=$ early-midseason.

${ }^{w}$ Calculated as described previously (Galletta et al., 1996; Khanizadeh and Fanous, 1992) using the Pedigree software (Khanizadeh and Prasher, 1997). A

larger index indicates very concentrated ripening and early ripening for the index of crop concentration and index of earliness, respectively.

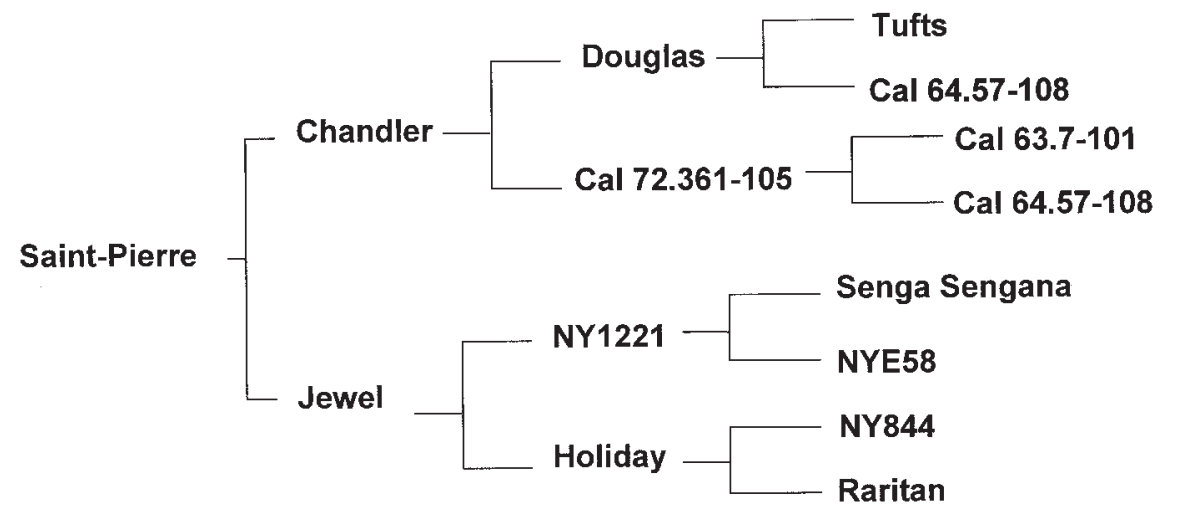

Fig. 2. Pedigree of 'Saint-Pierre' strawberry.

Table 2. Firmness, flavor, skin color, leaf disease susceptibility and shelf life of 'Saint-Pierre' and comparison cultivars at L'Acadie. ${ }^{\mathrm{z}}$

\begin{tabular}{lccccc}
\hline \hline Cultivar & Firmness $^{\mathrm{y}}$ & Flavor $^{\mathrm{y}}$ & ${\text { Skin } \text { color }^{\mathrm{y}}}^{\mathrm{n}}$ & $\begin{array}{c}\text { Leaf disease } \\
\text { susceptibility }^{\mathrm{y}}\end{array}$ & Shelf life $^{\mathrm{x}}$ \\
\hline Kent & 3.2 & 3.0 & 2.8 & 1.3 & 2.0 \\
Chambly & 3.6 & 3.3 & 3.8 & 3.9 & 3.0 \\
Bounty & 2.0 & 3.0 & 3.0 & 3.0 & 1.0 \\
Honeoye & 3.0 & 3.0 & 3.0 & 2.0 & 1.0 \\
Saint-Pierre & 4.0 & 4.0 & 2.0 & 1.9 & 5.0 \\
LSD $_{0.05}$ & 0.4 & 0.7 & 0.3 & 0.7 & 3.0
\end{tabular}

${ }^{\mathrm{z}}$ Averaged over 5 years from second year plantings (1995-99), minimum of four replications per year, data taken from a 1-m long representative portion of a 2-m matted row (width $50 \mathrm{~cm}$ ).

${ }^{y}$ Data were transformed to arcsin prior to analysis of variance (SAS Inst., 1988). Firmness: $1=$ very soft, $5=$ very firm; flavor: $1=$ poor, $5=$ excellent; skin color: $1=$ very pale, $5=$ dark red; leaf disease susceptibility: 1 = very susceptible, 5 = resistant. See Khanizadeh et al. (1994) for details on score evaluations.

${ }^{x}$ Number of days at room temperature for which the fruit were more than $95 \%$ marketable.

'Honeoye' to the six North American Eastern (NAE) races of Phytophthora fragariae (A1 to A6) based on the presence of red-stele and oospores in the root segments (Khanizadeh et al., 1997). 'Saint-Pierre' and 'Honeoye', at our substation in L'Acadie, had the same level of tolerance to Diplocarpon earlina Ell. \& Ev., Dendrophoma obscurans Ell. \& Ev. and Mycosphaerella fragariae (Tul.) Lindau, causal agents of leaf scorch, leaf blight, and leaf spot, respectively. row system in sandy soils and are also adapted to growing in compact or heavy soils. The fruit is ideal for shipping because of its long shelf life.

\section{Availability}

A patent is pending for 'Saint-Pierre' and plants are presently available from licensed nurseries in Quebec. Nonexclusive multiplication licences can be obtained from Agriculture and Agri-Food Canada. European nurseries can obtain a multiplication licence from Meiosis (Bradbourne House, Stable Block, East Malling, Kent ME19 6DZ). A limited number of plants are available for research purposes from the author (S.K.).

\section{Literature Cited}

Hébert, C., M.T. Charles, L. Gauthier, C. Willemot, S. Khanizadeh, and J. Cousineau. 2002. Strawberry proanthocyanidins: Biochemical markers for Botrytis cinerea resistance and shelf-life predictability. Acta Hort. 2(567):659-661.

Khanizadeh, S. 1994. Breeding strawberries for Eastern Central Canada, p. 183-187. In: H. Schmidt and M. Kellerhals (eds.). Progress in temperate fruit breeding. Kluwer Academic, The Netherlands.

Khanizadeh, S. and M.A. Fanous. 1992. Mathematical indices for comparing small fruit crops and trait similarity. HortScience 27:346-348.

Khanizadeh, S., A. Gruber, O. Carisse, D. Buszard, and P.O. Thibodeau. 1997. Red-stele susceptibility of advanced strawberry selections from Quebec. Acta Hort. 439:189-193.

Khanizadeh, S., J.Fortin, M.J.Lareau, and D. Buszard. 1994. Sensory evaluation of six strawberry cultivars after machine harvest, p. 249-254. In: H. Schmidt and M. Kellerhals (eds.). Progress in temperate fruit breeding. Kluwer Academic, The Netherlands.

'Saint-Pierre' is recommended for Eastern Central Canada, especially in areas where the climate is similar to that in the strawberry production areas of Quebec. Typically, strawberry production in Quebec occurs in areas with winter temperatures down to $-30{ }^{\circ} \mathrm{C}$ and warm and humid summers with an unpredictable mixture of sun and rain (drought some seasons, constant rain other seasons). 'SaintPierre' plants perform very well in a matted
Khanizadeh, S. and S.O. Prasher. 1997. Pedigree ${ }^{\odot}$ : A database program to draw pedigrees, trace traits, and view images of strawberry genotypes. Adv. Strawberry Research 16:67.

Galletta, G.J., J.L. Maas, J.M. Enns, J.C. Scheerens, R. Rouse, and R.F. Heflebower, Jr. 1996. Primetime strawberry. HortScience 31:1038-1042.

SAS Institute. 1988. Statistical analysis system. SAS/ STAT, SAS/BASIC guide for personal computers, version 6.04 (ed.). SAS Inst., Cary, N.C. 